\title{
Seasonal pattern of luteinizing hormone and testosterone pulsatile secretion in young adult red deer stags (Cervus elaphus) and its association with the antler cycle
}

\author{
J. M. Suttie ${ }^{1}$, P. F. Fennessy ${ }^{1}$, I. D. Corson ${ }^{1}$, B. A. Veenvliet ${ }^{1}$, \\ R. P. Littlejohn ${ }^{1}$ and K. R. Lapwood ${ }^{2}$
}

${ }^{1}$ Invermay Agricultural Centre, MAF Technology, Private Bag, Mosgiel, New Zealand; and

${ }^{2}$ Department of Physiology and Anatomy, Massey University, Palmerston North, New Zealand

Summary. Blood from stags aged 15 months $(n=6)$ was sampled at monthly intervals every $30 \mathrm{~min}$ for $24 \mathrm{~h}$ for 12 months, at $45^{\circ} \mathrm{S}$ in New Zealand. Three extra samplings each for $24 \mathrm{~h}$ were carried out at about the anticipated time of antler casting. All samples were analysed for luteinizing hormone (LH) and testosterone and the resulting data further analysed by the PULSAR pulse detection routine. The animals were kept indoors under natural daylength and were fed ad libitum. All animals were weighed, antler status and size recorded and testes diameter was measured on each sampling day. Mean LH and testosterone pulsatility and plasma concentrations varied seasonally. LH pulse frequency was low during autumn $(2.5$ pulses in $24 \mathrm{~h})$, winter $(1.0-1.5$ pulses in $24 \mathrm{~h}$ ) and early spring ( 1 pulse in $24 \mathrm{~h}$ ) and lowest in late spring $(0.2$ pulses in $24 \mathrm{~h})$ before rising in summer ( $1.0-4.0$ pulses in $24 \mathrm{~h})$. $\mathrm{LH}$ pulse amplitude and mean plasma concentration were low $\left(<1 \mathrm{ng} \mathrm{ml}^{-1}\right.$ ) from March to November (autumn-spring); both rose to a peak in January (summer) of 3.4 and $1.6 \mathrm{ng} \mathrm{ml}^{-1}$, respectively. Testosterone pulse frequency was generally similar to LH except that slightly more pulses of testosterone than of LH were detected from March to November and more pulses of LH from November to February (summer). Testosterone pulse amplitude fell from March to November $\left(5 \cdot 3 \mathrm{ng} \mathrm{ml}^{-1}\right.$ to undetectable) although there was a conspicuous peak in July (midwinter) of almost $5 \mathrm{ng} \mathrm{ml}^{-1}$. Testosterone pulse amplitude remained low until February (late summer) when it rose to $3.7 \mathrm{ng} \mathrm{m}^{-1}$. Mean testosterone concentrations were high in autumn $\left(2.7 \mathrm{ng} \mathrm{ml}^{-1}\right)$ during the breeding season, when the stags were 15 months old. Mean testosterone concentrations fell gradually during winter and reached a nadir in midspring of $0.2 \mathrm{ng} \mathrm{ml}^{-1}$. Testosterone concentrations were low during late spring to early summer $\left(0.2 \mathrm{ng} \mathrm{ml}^{-1}\right)$, but rose to a peak in late summer $\left(3 \cdot 7 \mathrm{ng} \mathrm{ml}^{-1}\right)$, when the stags were 26 months old. From 12 weeks before antler casting, LH pulses of low frequency $(0.2$ pulses in $24 \mathrm{~h})$ and low amplitude $\left(0 \cdot 1 \mathrm{ng} \mathrm{ml}^{-1}\right)$ were detected, resulting in diminishing mean testosterone. At the time of antler casting, no pulses of $\mathrm{LH}$ or testosterone were detected and mean concentrations of both hormones were very low or undetectable. After antler casting, $\mathrm{LH}$ increased to 4 pulses in $24 \mathrm{~h}$, but testosterone remained low $\left(<0.6 \mathrm{ng} \mathrm{ml}^{-1}\right)$ until the velvet antler was almost fully grown. High testosterone concentrations $\left(3.7 \mathrm{ng} \mathrm{ml}^{-1}\right)$ were associated with velvet antler cleaning in late summer. This study provides a description of the ontogeny of the seasonal nadir in mean testosterone in red deer stags, which is believed to facilitate antler casting and antler regeneration. 


\section{Introduction}

The seasonal changes in concentrations of reproductive hormones in adult red deer stags (Cervus elaphus) are known from studies in which stags were sampled infrequently (Lincoln, 1971) or given gonadotrophin-releasing hormone challenges (Fennessy et al., 1988). Although seasonal pulsatile luteinizing hormone $(\mathrm{LH})$ and testosterone hormone secretion patterns have been investigated in adult fallow deer bucks (Dama dama) (Asher et al., 1989) and in red deer (Lincoln \& Kay, 1979), complete studies of this kind have not been carried out in red deer over a full year with $24 \mathrm{~h}$ of sampling every month.

The seasonal cycle of growth and replacement of the antlers is physiologically linked to the seasonal rhythms of reproductive hormones (Wislocki et al., 1947; Chapman, 1975). Low plasma concentrations of testosterone are associated with antler casting and velvet antler growth; and high concentrations of testosterone are associated with the cleaning of the velvet to reveal hard dead bone, and the possession of hard antlers. Asher et al. (1989) studied pulsatile reproductive hormone secretion in polled (antlerless) bucks, but no conclusions relating pulsatile hormone secretion to the antler cycle could be drawn.

The present study investigated pulsatile LH and testosterone secretion in young adult red deer and related the seasonal changes in hormone release to changes in the antler cycle, particularly antler casting. The study is a continuation of that reported by Suttie et al. (1991) into a second year, using the same animals and similar experimental techniques.

\section{Materials and Methods}

\section{Animals and sampling}

Six red deer stags were kept indoors from 15 to 26 months old, from March to February (southern hemisphere). Details of animal husbandry and sampling of these animals have been presented elsewhere (Suttie et al., 1991). The animals were bottle fed as calves to induce tameness and were fed a barley-based concentrate diet ad libitum. They were penned individually although they could see, hear, smell and touch their immediate neighbours.

At monthly intervals and on three other occasions at about the anticipated time of antler casting (Fennessy \& Suttie, 1985), blood samples were withdrawn at intervals of $30 \mathrm{~min}$ for $24 \mathrm{~h}$ from each stag, via a jugular catheter inserted under local anaesthesia immediately before blood sampling began, and placed into heparinized tubes. The blood was centrifuged at $2000 \mathrm{~g}$ for $15 \mathrm{~min}$ and the resulting plasma frozen at $-20 \mathrm{C}$ until assay. The stags were weighed, antler status and length were recorded and testes diameter was measured with vernier callipers.

\section{Hormone analysis}

LH and testosterone (after solvent extraction) were measured by radioimmunoassay as previously described (Fennessy et al., 1988). The LH assay had a sensitivity of $0.06 \mathrm{ng} \mathrm{ml} \mathrm{'.} \mathrm{The} \mathrm{inter-} \mathrm{and} \mathrm{intra-assay} \mathrm{coefficients} \mathrm{of}$ variation for three pools of plasma containing $4 \cdot 21,2.49$ and $0.44 \mathrm{ng} \mathrm{ml}{ }^{\prime}$ were 11.4 and $9 \cdot 6,14.8$ and 6.1 and 4.6 and $8.2 \%$, respectively. The extraction efficiency of testosterone was $>95 \%$ and values were corrected accordingly. The sensitivity of the testosterone assay was $0.09 \mathrm{ng} \mathrm{ml}^{-1}$. The inter- and intra-assay coefficients of variation for three pools of plasma containing $5 \cdot 47,3 \cdot 77$ and $0.41 \mathrm{ng} \mathrm{ml}{ }^{\prime}$ were 13.7 and $10 \cdot 1$, and $19 \cdot 3$ and $10 \cdot 1$, and $7 \cdot 4$ and $13.3 \%$, respectively.

\section{Pulse detection and biometrics}

LH and testosterone pulse profiles were analysed for each stag on each sampling day using the pulse identification routine PULSAR (Merriam \& Wachter, 1982). The assay standard deviation as a function of dose $(x)$, was estimated by $\left(1 \cdot 71 x^{2}-2 \cdot 44 x+8 \cdot 41\right) / 100$ for LH and $\left(-0 \cdot 492 x^{2}+11 \cdot 81 x+1 \cdot 87\right) / 100$ for testosterone. Remaining inputs were as previously described (Suttie et al., 1991).

Mean concentration, pulse amplitude and pulse frequency were analysed with ANOVA followed by the Newmann-Keuls' test, for each hormone in each sampling period. As individual stags cast their previous hard antlers over 3 weeks, $\mathbf{L H}$ and testosterone data were analysed in relation to time, in weeks, before and after antler casting. 


\section{Results}

\section{Body size and antler cycle}

The stags remained at a mean weight of about $100 \mathrm{~kg}$ until October-November (spring) then gained weight slowly until a peak weight of about $120 \mathrm{~kg}$ was reached in February (late summer, Fig. 1). The previous hard antlers were cast in October and branched antlers regrew to a length of $56 \pm 5 \mathrm{~cm}(\bar{x} \pm$ SEM) in the 3 months after casting. Growth of these antlers was complete in January (summer) and the antlers were clean of velvet in February (Fig. 1). Mean testis diameter gradually fell from $3 \cdot 2 \pm 0 \cdot 2 \mathrm{~cm}$ in March (autumn) when the stags were 15 months old to $1.8 \pm 0 \cdot 1 \mathrm{~cm}$ in November (the following spring), when the stags were 24 months old (Fig. 1). Testis diameter increased to a maximum value of $3.3 \pm 0.2 \mathrm{~cm}$ in February.

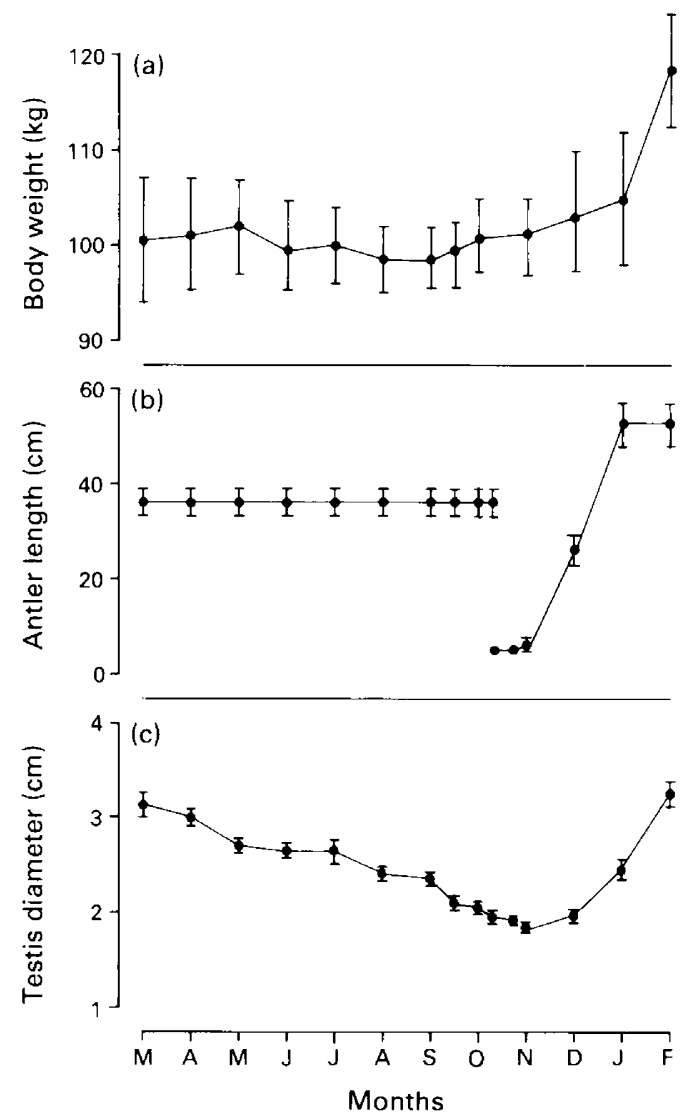

Fig. 1. (a) Mean \pm SEM body weight, (b) antler length and (c) testis diameter for six red deer stags in each month of the study.

\section{Pulsatile LH and testosterone secretion}

In March, the LH pulses were small, but each preceded a large pulse of testosterone (Fig. 2). From April (autumn) to September, LH pulses were very small or undetectable, yet discrete pulses of testosterone were measured. From May (late autumn) onwards (particularly as shown by deer 


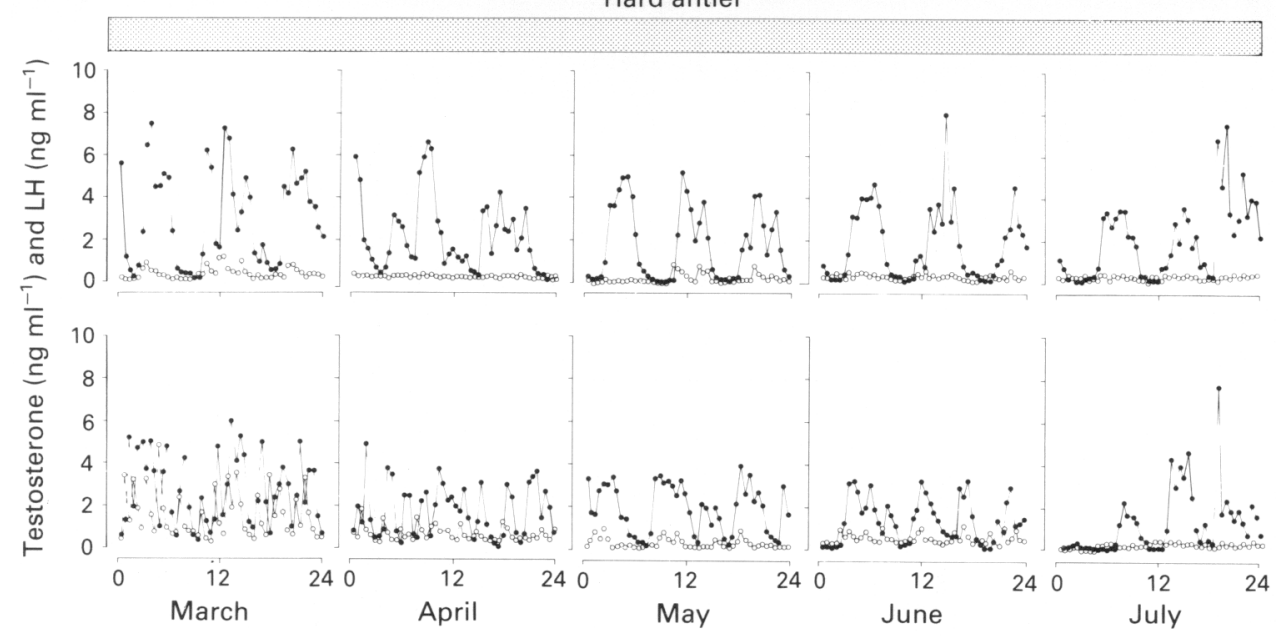

Hard antler
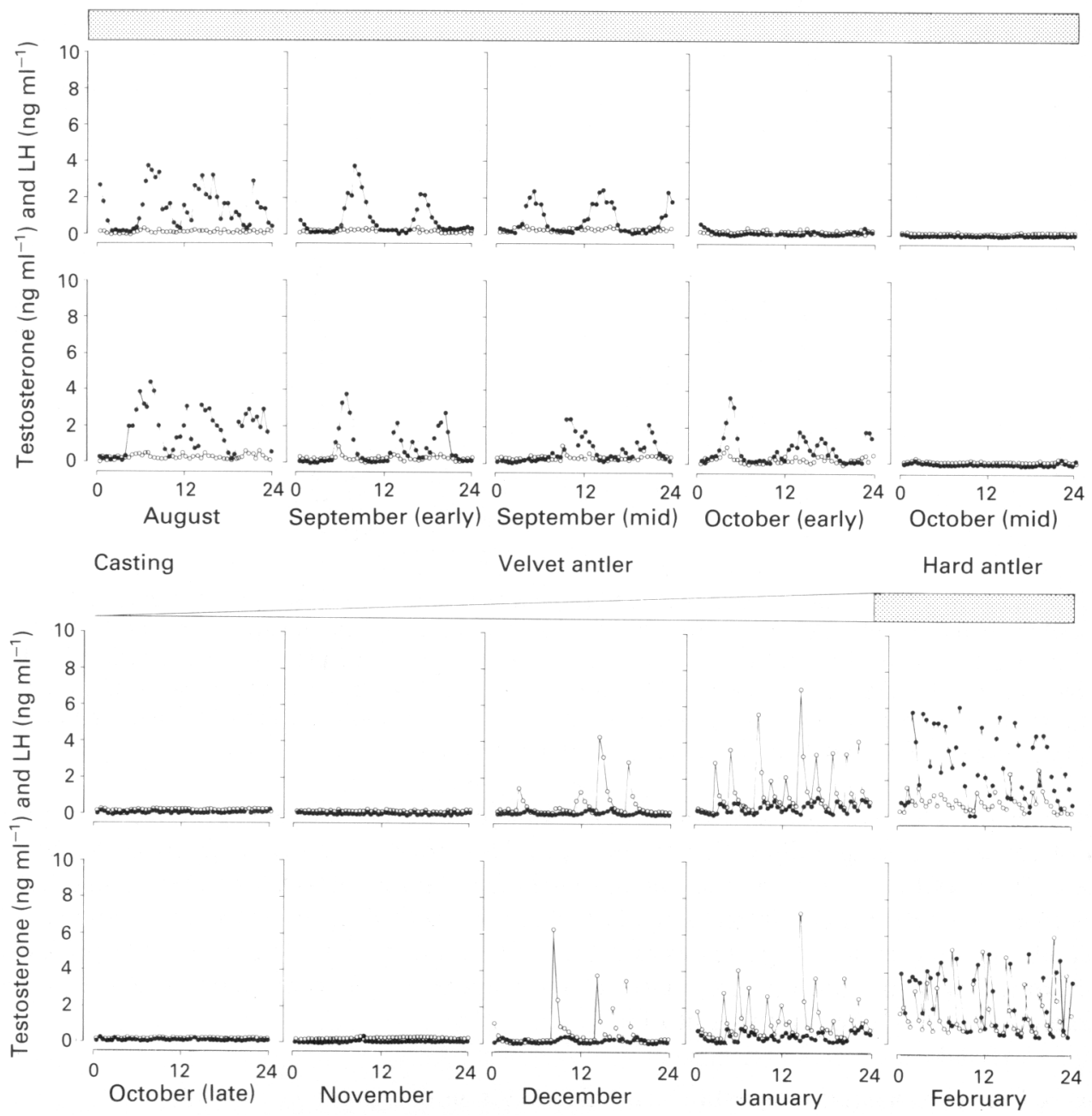

Fig. 2. Pulse profiles for luteinizing hormone $(\mathrm{LH}, O)$ and testosterone $(\bullet)$ for each sampling period for two typical red deer stags. Antler status is shown diagrammatically above each. 

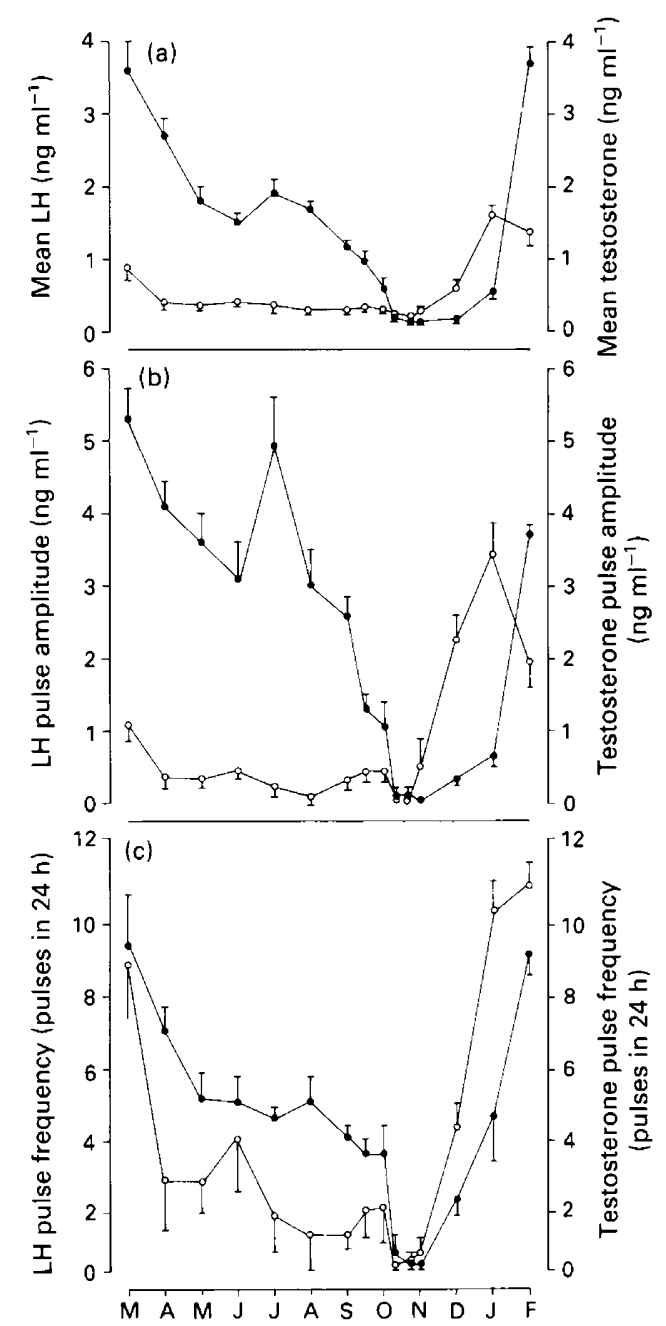

Fig. 3. (a) Mean, (b) pulse amplitude and (c) pulse frequency of luteinizing hormone (LH, $O$ ) and testosterone $(O)$ for each sampling period in red deer stags. Each value is the mean \pm SEM for six stags. Mean LH and testosterone values are the means of plasma concentration in 48 blood samples taken at intervals of $30 \mathrm{~min}$ for $24 \mathrm{~h}$ each sampling period. Pulse amplitude is taken directly from the PULSAR output and is the increment between the limit of detection of the assay and the observed peak detected by the pulse routine.

no. 4, in Fig. 2), testosterone was secreted in 3-4 major episodes each day although the episodes did not correspond temporally with secretory episodes detected in other stags. After August (late winter), the amplitude of the testosterone outbursts fell until, in mid-October, no plasma LH and testosterone were detectable. Infrequent LH pulsatility resumed in November, but only very low amplitude or no testosterone pulses were detected. In January, rapid frequency LH pulses were accompanied by small, but discrete, pulses of testosterone. In February, large discrete pulses of testosterone followed smaller pulses of $\mathrm{LH}$.

\section{Pulsatile $\mathrm{LH}$ and testosterone secretion in relation to season}

Mean LH fell from $0.8 \pm 0.2 \mathrm{ng} \mathrm{m}^{-1}$ in March to about $0.4 \mathrm{ng} \mathrm{m}^{-1}$ from April to October (Fig. 3). During October, mean LH was $0.2 \pm 0.05 \mathrm{ng} \mathrm{ml}^{-1}$, then rose to a peak of $1.6 \pm 0.1 \mathrm{ng} \mathrm{ml}^{-1}$ 


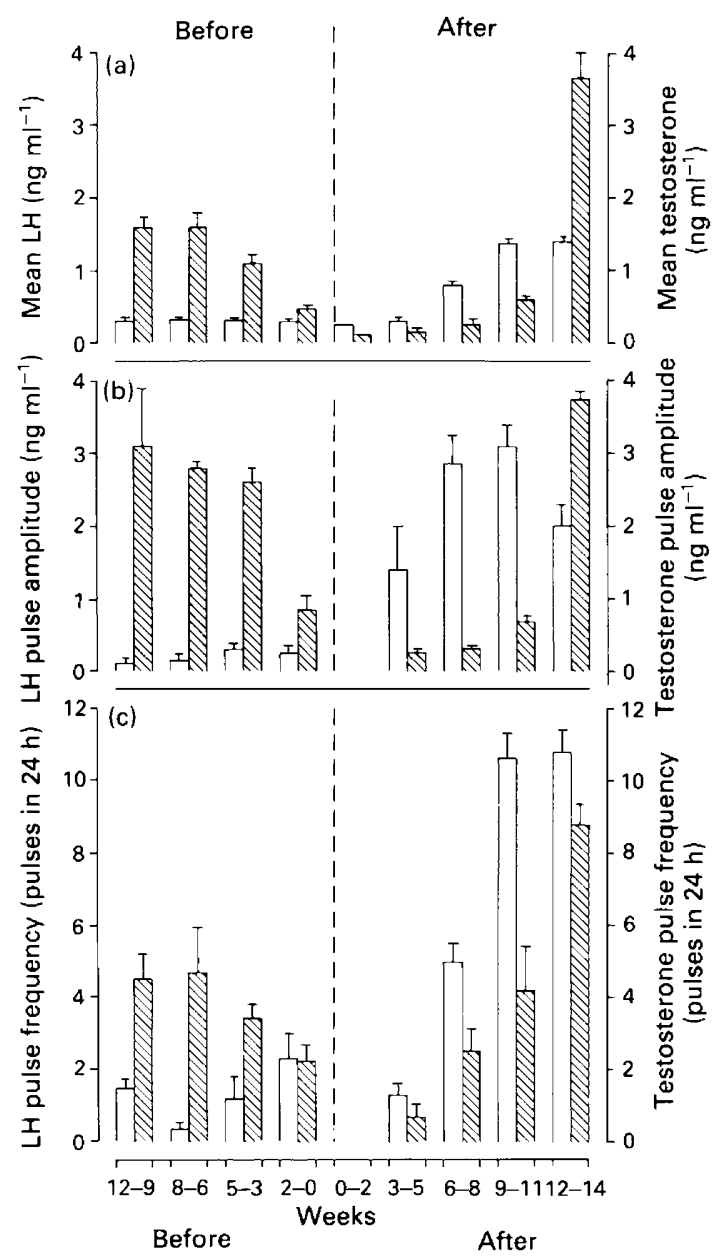

Fig. 4. (a) Mean, (b) amplitude and (c) frequency of luteinizing hormone (LH, $\square$ ) and testosterone $(\mathbb{Q})$, in relation to antler casting in red deer. Data (mean \pm SEM) are presented as deviations from antler casting in 2-week blocks so that each stag is represented at least once, but no more than twice, in each block. ANOVA revealed significant differences in all parameters $(P<0.001)$ with respect to week block. All stags cleaned their antlers of velvet between weeks 12 and 14.

in January. Mean testosterone fell steadily from $3.6 \pm 0.4 \mathrm{ng} \mathrm{ml}^{-1}$ in March to $0.1 \mathrm{ng} \mathrm{ml}^{-1}$ (i.e. undetectable) in October and November. A peak testosterone concentration of $3.7 \pm 0.3 \mathrm{ng} \mathrm{ml}^{-1}$ was detected in February.

LH pulse amplitude was low $\left(<0.5 \mathrm{ng} \mathrm{ml}^{-1}\right)$ from April to November, but increased to a maximum in January of $3.4 \pm 0.4 \mathrm{ng} \mathrm{ml}^{-1}$ before falling to $2.0 \pm 0.4 \mathrm{ng} \mathrm{ml}^{-1}$ in February (Fig. 3). Testosterone pulse amplitude fell from March to June, but rose to almost $5 \mathrm{ng} \mathrm{m}^{-1}$ in July. It then continued to fall until October, when pulses of testosterone were undetectable. Testosterone pulse amplitude increased slowly in December and January to $0.6 \pm 0.01 \mathrm{ng} \mathrm{ml}^{-1}$ and then rose sharply to $3 \cdot 7 \pm 0 \cdot 2 \mathrm{ng} \mathrm{ml}^{-1}$ in February.

LH and testosterone pulse frequency were both about nine pulses in $24 \mathrm{~h}$ in March, but the frequency of LH pulses fell sharply until none was detected in October (Fig. 3); an exception was a slight increase in LH pulse frequency in June. LH pulses were detected in November and 
the frequency rose to a peak of $11 \pm 0.6$ pulses in $24 \mathrm{~h}$ in February. Testosterone pulse frequency fell from about nine pulses in $24 \mathrm{~h}$ in March to virtually nil in October-November, but rose in summer and autumn to $8.8 \pm 0.6$ pulses in $24 \mathrm{~h}$ following the increase in LH pulse frequency.

\section{Pulsatile $\mathrm{LH}$ and testosterone secretion in relation to the antler cycle}

There were no pulses of $\mathrm{LH}$ or testosterone at the time of antler casting or for 2 weeks after (Fig. 4). Mean LH was low $\left(<0 \cdot 3 \mathrm{ng} \mathrm{m}^{-1}\right)$ until 6-8 weeks after antler casting. Mean testosterone plasma concentrations fell from $1.6 \pm 0.2 \mathrm{ng} \mathrm{ml}^{-1}$ at $9-7$ weeks before antler casting to $0 \cdot 15 \pm 0 \cdot 1 \mathrm{ng} \mathrm{ml}^{-1}$ (essentially the limit of detection of the assay) at antler casting. Thereafter, testosterone concentrations remained low $\left(<0.25 \mathrm{ng} \mathrm{ml}{ }^{1}\right)$ until $9-11$ weeks after casting. The highest mean testosterone concentration $\left(3 \cdot 7 \pm 0.4 \mathrm{ng} \mathrm{ml}^{-1}\right)$ was detected 12-14 weeks after antler casting, when the antlers were clean of velvet.

LH and testosterone pulse amplitude largely followed the same pattern as the mean concentrations (Fig. 4). LH pulse frequency ranged from 0.3 to 2.3 pulses in $24 \mathrm{~h}$ before antler casting, but was zero at antler casting and for the next 2 weeks. However, 3-5 weeks after antler casting LH pulse frequency had begun to increase. Testosterone pulse frequency fell from 8-6 weeks before antler casting and was zero at the time of casting. Testosterone pulse frequency rose after antler casting more slowly than the increase in LH pulse frequency.

\section{Discussion}

The stags were about $10 \mathrm{~kg}$ lighter at 26 months of age than values reported by Fennessy et al. (1981). The frequent blood sampling in spring may have adversely influenced body growth over this period. The timing of antler casting, in early October, was consistent with previous data from this research centre (Fennessy \& Suttie, 1985). Likewise, antler size was similar to data previously reported (Fennessy \& Suttie, 1985). Testis regression and development closely followed both the pattern and size for red deer stags of similar age in the studies of Suttie (1981).

Seasonal variations in pulsatile $\mathrm{LH}$ and testosterone release have been demonstrated in red deer (Lincoln \& Kay, 1979) and fallow deer (Asher et al., 1989). The present studies confirm and extend these findings. The rut or mating season in autumn is characterized by high mean testosterone concentrations, presumably a result of the high-frequency, low-amplitude LH pulses. During winter, LH pulse frequency is reduced and, although testosterone concentrations only decrease slowly, by spring concentrations of LH and testosterone are low. Red deer appear to differ from fallow bucks in this respect: Asher et al. (1989) found very low concentrations of testosterone with few pulses of LH or testosterone from May (late autumn) to January (summer) in the bucks they studied. We speculate that as testosterone secretion over winter in red deer is maintained under conditions of very low $\mathrm{LH}$ secretion and pulsatility, there may be a species difference in testicular sensitivity to gonadotrophins during winter. Alternatively the difference may reflect the fact that Asher et al. (1989) sampled 5-6-year-old bucks, compared with 2-year-old stags in the present study, and their bucks were kept outdoors, whereas our stags were indoors.

Although $\mathrm{LH}$ and testosterone pulse frequency broadly followed the same seasonal pattern, the LH pulse frequency as measured by the PULSAR peak detection routine was seldom the same as the testosterone pulse frequency. This discrepancy did not occur at random; during winter when the testes were decreasing in size, measured LH pulse frequency was invariably less than testosterone and during spring, when the testes were developing, the opposite was observed. Although it is possible that the sample frequency or the assay sensitivities were insufficient to detect pulses, there are possible physiological explanations for this effect. During the period of testicular regression, the testis might retain acute sensitivity to gonadotrophins such that small (undetected by PULSAR) pulses of LH could 
elicit a testosterone pulse. If the testicular tissue sensitivity to $\mathrm{LH}$ took time to develop, the testis might not respond to every pulse of $\mathrm{LH}$ in spring. This putative pattern of seasonal changes in tissue sensitivity pertain to the discussion and reproductive hormones and antler development below.

The general decrease in LH pulse frequency was interrupted in June by a slight increase and this was followed one month later by an increase in mean testosterone and pulse amplitude. Out-ofseason reproductive activity has been reported by Haigh et al. (1984) in wapiti, by Suttie \& Kay (1985) in red deer and by Asher et al. (1989) in fallow deer. The function of this is not known, but its occurrence during the transition from decreasing to increasing day length, i.e. about the time of the winter solstice, means that it is precisely 6 months from the transition from increasing to decreasing days. In a study of red deer stags in a manipulated photoperiod, Suttie et al. (1989) observed that,

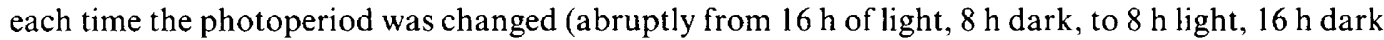
or vice versa), there was an increase in the LH responsiveness to gonadotrophin-releasing hormone. It may be that deer respond rapidly to all photoperiod changes, then either continue to respond or not, depending on the direction of the photoperiodic change.

Studies by Wislocki et al. (1947) established that testosterone is necessary for stags to retain hard antlers. They showed that castration of stags in hard antler resulted in antler casting. Lincoln et al. (1972) showed that testosterone implants given to entire stags prevented antler casting. Lincoln \& Kay (1979) and Suttie et al. (1984) found that LH and testosterone pulsatile secretion was minimal at the time of antler casting, but the present study offered the opportunity to investigate in detail the ontogeny of the low hormonal secretion and their effects on early velvet antler growth. From 11 weeks before antler casting, LH pulses are of low amplitude $\left(<0.3 \mathrm{ng} \mathrm{ml}^{-1}\right)$ and of low frequency $(<2$ pulses in $24 \mathrm{~h}$ ). Such low LH stimulation of the testis results in decreasing testosterone pulses of diminishing amplitude resulting in low mean plasma concentrations. At antler casting, there are no detectable pulses of LH or testosterone and mean concentrations of both hormones are at the limit of detection of the assays. This is the stage of the seasonal reproductive endocrine cycle when the stag is in the most regressed state. Even in Soay rams, LH pulses were detected, by Lincoln (1976), during total reproductive regression, so it seems that such absolute quiescence, as shown by stags, is unusual. This has led to speculation that some (unknown) physiological factor is actively suppressing LH secretion in this species. Suttie \& Kay (1985) speculated that prolactin, which is high in stags in spring, if it functioned as an antigonadotrophin, might fulfil this role.

There was no evidence in the present study for a pre-antler casting rise in plasma testosterone concentrations, which was suggested by Sempere \& Boissin (1982); testosterone fell uniformly for at least 11 weeks before casting. It is unlikely that it is the withdrawal of testosterone per se that facilitates osteoclast action in antler autotomy. Rather, withdrawal of testosterone permits an inflammatory response, which allows osteoclast action to ensue, perhaps via a prostaglandinmediated phenomenon; as prostaglandin $\mathrm{E}_{2}$ is known to be involved in bone resorption and inflammation (Klein \& Raisz, 1970).

The increase in LH pulse frequency after antler casting is considered to be a consequence of the loss of steroid negative feedback from the testis and a change in the central nervous system control of gonadotrophin-releasing hormone. The stag can be thought of as almost a functional castrate for the first few weeks of velvet antler growth. The fact that the testis seems to respond very slowly to $\mathrm{LH}$ stimulation in terms of testosterone release is of interest. As high testosterone concentrations are inimical to antler growth (Wislocki et al., 1947), it appears that testosterone release may be suppressed to facilitate velvet antler growth. The identity of the putative suppressor is unknown.

The present study confirms earlier findings that high plasma concentrations of testosterone are associated with antler cleaning (Lincoln \& Kay, 1979; Suttie et al., 1984). The concentrations of testosterone during winter are much higher than those reported by Asher et al. (1989) in fallow deer, leading to the speculation that high winter testosterone concentrations are necessary in red deer, but not in fallow deer, for the winter retention of hard antlers. 


\section{References}

Asher, G.W., Peterson, A.J. \& Bass, J.J. (1989) Seasonal pattern of $\mathrm{LH}$ and testosterone secretion in adult male fallow deer, Dama dama. Journal of Reproduction and Fertility 85, 657-665.

Chapman, D.I. (1975) Antlers - bones of contention. Mammal Review 5, 121-173.

Fennessy, P.F. \& Suttie, J.M. (1985) Antler growth: nutritional and endocrine factors. In Biology of Deer Production, pp. 239-250. Eds P. F. Fennessy \& K. R. Drew. The Royal Society of New Zealand, Bulletin 22.

Fennessy, P.F., Moore, G.M. \& Corson, I.D. (1981) Energy requirements of red deer. Proceedings of the New Zealand Society for Animal Production 41, 167-173.

Fennessy, P.F., Suttie, J.M., Crosbie, S.F., Corson, I.D., Elgar, H.J. \& Lapwood, K.R. (1988) Plasma LH and testosterone responses to gonadotropin releasing hormone in adult red deer Cervus elaphus stags during the annual antler cycle. Journal of Endocrinology 117, $35-41$.

Haigh, J.C., Cates, W.F., Glover, G.J. \& Rawlings, N.C. (1984) Relationships between seasonal changes in serum testosterone concentrations, scrotal circumference and sperm morphology of male wapiti (Cervus elaphus). Journal of Reproduction and Fertility 70, 413-4!8.

Klein, D.C. \& Raisz, L.G. (1970) Prostaglandins: stimulation of bone resorption in tissue culture. Endocrinology 86, 1436.

Lincoln, G.A. (1971) The seasonal reproductive changes in the red deer stag (Cervus elaphus). Journal of Zoology, London 163, 105-123.

Lincoln, G.A. (1976) Seasonal variation in the episodic secretion of luteinizing hormone and testosterone in the ram. Journal of Endocrinology 69, 213-226.

Lincoln, G.A. \& Kay, R.N.B. (1979) Effects of season on the secretion of LH and testosterone in intact and castrated red deer stag (Cervus elaphus). Journal of Reproduction and Fertility 55, 75-80.
Lincoln, G.A., Guinness F.E. \& Short, R.V. (1972) The way in which testosterone controls the social and sexual behaviour of the red deer stag (Cervus elaphus). Hormones and Behavior 3, 375-396.

Merriam, G.R. \& Wachter, K.W. (1982) Algorithms for the study of episodic hormone secretion. American Journal of Physiology 243, E310-E318.

Sempere, A.J. \& Boissin, J. (1982) Neuroendocrine and endocrine control of the antler cycle in roe deer. In Antler Development in Cervidae, pp. 109-122. Ed. R. D. Brown. Caesar Kleberg Wildlife Research Institute, Kingsville, TX.

Suttie, J.M. (1981) The influence of nutrition and photoperiod on the growth, development and endocrine status of captive red deer and Soay rams. $\mathrm{PhD}$ thesis, University of Aberdeen.

Suttie, J.M. \& Kay, R.N.B. (1985) Influence of plane of winter nutrition on plasma concentrations of prolactin and testosterone and their association with voluntary food intake in red deer stags (Cervus elaphus). Animal Reproduction Science 8, 247-258.

Suttie, J.M., Lincoln, G.A. \& Kay, R.N.B. (1984) The endocrine control of antler growth in red deer stags. Journal of Reproduction and Fertility 71, 7-15.

Suttie, J.M., Fennessy, P.F., Corson, I.D., Laas, F.J., Elgar, H.J. \& Lapwood, K.R. (1989) LH and testosterone responses to $\mathrm{GnRH}$ in red deer (Cervus elaphus) stags kept in a manipulated photoperiod. Journal of Reproduction and Fertility 85, 213-219.

Suttie, J.M., Fennessy, P.F., Crosbie, S.F., Corson, I.D., Laas, F.J., Elgar, H.J. \& Lapwood, K.R. (1991) Temporal changes in luteinizing hormone and testosterone and their relationship with the first antler in red deer (Cervus elaphus) stags from 3 to 15 months of age. Journal of Endocrinology 131, 467-474.

Wislocki, G.B., Aub, J.C. \& Waldo, C.M. (1947) The effects of gonadectomy and administration of testosterone propionate on the growth of antlers in male and female deer. Endocrinology 40, 202-224.

Received 25 July 1991 